Editorial

\title{
Design for Sustainability: The Need for a New Agenda
}

\author{
Garrath T. Wilson * (1) and Tracy Bhamra \\ School of Design and Creative Arts, Loughborough University, Loughborough LE11 3TU, UK; \\ T.Bhamra@lboro.ac.uk \\ * Correspondence: g.t.wilson@lboro.ac.uk
}

Received: 23 April 2020; Accepted: 27 April 2020; Published: 30 April 2020

check for updates

\begin{abstract}
Design for Sustainability is not the panacea we hoped it would be when it was first introduced in the latter part of the 20th century. Today, the health of both our environment and our societies is at a critical state, a breaking point, with piecemeal solutions offered as social-media-friendly rallying points, such as the European Parliament approved ban on single-use plastics, whilst fundamental, and arguably less 'exciting', issues such as loss of biodiversity, overpopulation, and climate change are shuffled to the back. It can be argued, however, that the awareness of the concept of sustainability and the need to reduce the negative human impact upon the environment and society has grown significantly and, consequently, has moved up the global agenda; this is evidenced by the 2015 United Nations Climate Change Conference. However, it is also clear that the role of Design for Sustainability within this agenda is not providing the solutions necessary to manifest the level of change required. Traditional approaches are not working. This Special Issue of Sustainability seeks to readdress this with eight papers that push the frontier of what Design for Sustainability could be-and possibly must be-across the broad spectrum of design disciplines.
\end{abstract}

Keywords: design for sustainability; radical change; future trends; speculative design; alternative design models and strategies

\section{Introduction}

In 2019 the Bramble Cay melomys (Melomys rubicola) was formally declared by the Australian Minister for the Environment to be extinct [1,2]. Prior to its extirpation this relatively large mouse lived on a low-lying cay the size of approximately five international rugby pitches, in the straits between the northern tip of Australia and Papua New Guinea. Following repeated episodes of ocean inundation, due to both a rise in sea-levels and an increase in extreme weather events, the total vegetated area of this small island was reduced to 0.0065 ha (just under a quarter of the size of a tennis court) $[1,3,4]$. Either due to the dramatic devastation of habitat from saltwater or the severity of storm activity, which may have literally washed them off the face of the Earth, this rodent species is the first documented mammalian extinction due primarily to human-induced climate change [3,5]. The Bramble Cay melomys, therefore, is the first anthropogenic victim not of tomorrow but of today, dispelling any notion that climate change is a threat for (the cliché and always conveniently over the horizon) 'future generations' to suffer and deal with. A threat can be defined as a state of intention to cause damage; we are already past that point and need to start acting accordingly.

The sorry decline of the Bramble Cay melomys serves as a poignant demonstration of our accelerating trajectory towards, and in some cases already exceeding, several planetary boundaries [6,7]. The socio-economic systems in which we are living and are inextricably tangled in are both globally pervasive and perverse $[8,9]$, but climate change is only one sign of the ongoing abuse resulting in heat waves and droughts, heavy precipitation events, and a rapid decrease of ice sheet mass which in turn 
is raising sea levels [10-12]. Other signs of this negative hegemonic relationship include the significant rate of biodiversity loss (the extinction rate) and damage to the nitrogen cycle, which may result in irreversible changes to ecosystems but also a decline in food production resilience (e.g., crops capable to withstand changing environmental conditions, or pollinating animal species) [12-14]. Whether it started 50,000 years before the present with near global megafauna extinction due to hunting, or since the 1960s with an exponential rise in human produced chemical compounds (such as plastic), there is also a growing consensus that the impact of human activity upon the Earth has been of such a rate of acceleration, scale, and impact that we have even moved into a new geological epoch-The 'Age of Humans', or the Anthropocene [6,15]; not a title we should be proud of.

But whilst it is worth briefly reminding ourselves of the climate change discourse (although there is a growing trend towards 'climate crisis' (e.g., The Guardian's explicit change in language [16]) and/or 'climate emergency' (e.g., as declared by the Parliament of the United Kingdom [17]) as a framing that envelopes also the urgency of the issues) the bottom line is not new or surprising, although perhaps the true(r) extent of the impact and damage is only more recently being fully reported and contextualized (for example, the recent global assessment report on biodiversity and ecosystem services [13]). The 'Brundtland Report' [18], the United Nations commissioned report held as the key definer of 'sustainable development', is now over 30 years old (although the green movement itself has even earlier origins [19]). Within its pages the report is explicit in its call for action, stating,

“... not only do vastly increased human numbers and their activities have [the power to radically alter planetary systems], but major, unintended changes are occurring in the atmosphere, in soils, in waters, among plants and animals, and in the relationships among all of these ... We are unanimous in our conviction that the security, well-being, and very survival of the planet depend on [social and economic] changes, now." (p. 37, [18])

\section{New Direction for Design}

Three decades ago the line in the sand was drawn, and 'common endeavours' were proposed, yet whilst the definition of sustainable development has been tweaked, refined, expanded, and rebranded towards a more complex and nuanced dynamic systems model with a balanced focus on both environmental and societal prosperity [20,21], response in terms of operationalization, in particular from the design discipline, has arguably had limited positive impact.

The argument here is not that design as a discipline has not developed in response to critical issues and attempts made to correct the course. The work of Papanek (see: Design for the Real World: Human Ecology and Social Change [22]) did much to drive the concept of designers as socially and ecologically intelligent professionals, which in turn led to more ethical Design for Sustainability approaches to production and consumption [19]. These approaches are typically depicted as a continuum from product level green design and eco-design through to socio-technical system level transition design [20]. The issue here is that despite designers becoming increasingly aware of their role [23] and its expanding remit to solve complex problems through responsible design (from new physical/digital product development through to service and systems design for a sustainable now or a sustainable future), the level of change required has simply not come to pass. As part of this Special Issue Hernandez in his paper Sustainable Product-Service Systems and Circular Economies [24] explores the reasons why Sustainable Product-Service Systems in particular, have not been implemented despite providing a useful approach towards realising significant reductions in resource consumption. He identifies that Circular Economies can provide the necessary framework to enable this implementation and proposes combining the two approaches in order that change can start to happen within design.

Recent projections suggest that even if all signed governments achieved their legally binding commitments to the Paris Climate Change Agreement [25] global warming will still hit $3.3^{\circ} \mathrm{C}$ by 2100 [26], which will have disastrous global consequences [27]. As global citizens we are not on target to achieve this, as responsible global designers we have not been the required facilitators to realise this. To be clear, we are not naively suggesting that this is the sole responsibility of design as the silver 
bullet that can solve all of the afore mentioned issues, but design certainly has a stronger role to play in tandem and/or in parallel with other socially impacting (even manipulating) fora such as systems of politics and economy.

Exploring alternative directions within this Special Issue, Li et al. in their paper A Design Thinking-Based Study of the Prospect of the Sustainable Development of Traditional Handicrafts [28] assess the sustainable value of traditional handicraft design and identified four dimensions 'material and innovative value', 'handicraft and cultural value', 'empirical and local value', and 'sharing and interactive value'. They found that culture accounts for a large proportion of the sustainable value of handicraft products and consider that sustainable design strengthens the coordinating force among humans, objects, and the environment in the dimension of value. The other key paper related to this within this Special Issue is by Corsini and Moultrie, titled Design for Social Sustainability: Using Digital Fabrication in the Humanitarian and Development Sector [29], which focuses on social issues within Design for Sustainability and specifically how digital fabrication can be used to realise this within a humanitarian context. They argue that the lack of focus on social issues within Design for Sustainability is limiting sustainable development in the humanitarian and development sector and their paper investigates the ways in which designers can practically apply Design for Social Sustainability (DfSS). Their DfSS framework is specifically applied within projects using digital fabrication in the humanitarian/development sector (DF4D) and demonstrates how digital fabrication can support socially sustainable outcomes.

Gaziulusoy and Öztekin's Special Issue paper, Design for Sustainability Transitions: Origins, Attitudes and Future Directions [30], takes the concept further by looking at Design for Sustainability transitions (DfST). They demonstrate that the emergence of the concept dates back to the late 1990s, however, there is now a significant diversity of theories influencing theoretical development and practice which indicates a lack of alignment and unification in theoretical foundations. DfST draws on theories of sustainability science, systems innovations and socio-technical transitions theories, social practice theory, post-normal science, complex adaptive systems theory, product-service systems, futures studies, strategic niche management, needs theory, social psychology, indigenous knowledge, holism, Goethean science and alternative economies. The preliminary practice and real-world applications of this emerging field will provide empirical inputs to the theoretical developments and help develop tools and methodologies.

Traditional directions, put bluntly, have not worked and that therefore is the value in exploring new directions such as those presented within this Special Issue.

\section{Redefining Design for Sustainability}

Other than the urgency of the dire issues outlined above, why is now the right time to have a Special Issue on Sustainability that seeks to push the frontier of what Design for Sustainability could be-and needs to be-across the broad spectrum of design disciplines; including product design, user experience design, service design etc.? From our perspective, the consequences of the limited impact of design and its failure to provide both the required direction and leadership is being compounded by the role of media in its presentation of planetary issues, and the accompanying rise of the antiscience movement.

Particularly within the Global North, the perception of authentic and 'real' nature is a mediated and groomed experience [31]. Our sensorial connections with the environment within the everyday, such as gardens or parks for example, are a curated vignette which simulates the experience of 'the great outdoors'. Trees are planted in neat rows; grass is mechanically shortened; and plants that are designated as out of place-weeds-need to be removed, all to maintain and police a cultural idea of aesthetic harmony within our square plot of the 'natural' world. Nature artificial is to an extent shielding us against the cause and effect of our actions on nature real. We do not see the Antarctica ice sheets melting and coral reefs dying, we do not see large scale Brazilian deforestation and the impact upon flora that has not even been named yet, and we did not see the death of the Bramble Cay melomys. 
Therefore, whilst some are more attuned to decaying planetary conditions within their local environs, for example recognising the increasing frequency and severity of heatwaves as abnormal [32] or have noted a decline in bumble bee abundance [33]; for the rest without direct access to such environmental realities or scientific fact the message becomes communicated and translated through other media, such as the television, the internet, and social media platforms. As part of this Special Issue, Gatto and McCardle in their paper Multispecies Design and Ethnographic Practice: Following Other-Than-Humans as a Mode of Exploring Environmental Issues [34] take the position that by engaging with other-than-human viewpoints, here building upon post-humanist and ecosophy theories and the ethnographic method of 'following the plant', the focus of sustainable design intent can be de-centralised away from the human towards multispecies participants. The value of this, they argue, is that environmental concerns can be intelligently probed and explicitly considered without an assumed position of human privilege and associated capitalist needs. Within this approach, nature artificial is circumvented through improved engagement and situated experiences with nature.

Without such approaches these curated visions could lead to the condition of hyperreality [35], where the collective repetition of images and messages distorts and overpowers our perception of reality. Digital reality replaces actual lived sensorial reality, with the narrative becoming mediated by human actors with an agenda. In the context of climate change, at best these agendas can lead to a selected narrative with benevolent intent. For example, the BBC's Blue Planet series [36] attempts in one episode to create an emotive connection between the viewer, plastic waste (and microplastics) in the ocean and its impact on marine life:

"A mother [short-finned pilot whale] is holding her newborn young. It's dead. She is reluctant to let it go and has been carrying it around for many days. In top predators like these, industrial chemicals can build up to lethal levels... and plastic could be part of the problem."

This documentary has in turn led to a surge in public awareness in the UK and Europe leading to calls for a reduction in plastic waste. Even the First Vice-President of the European Commission, Frans Timmermans, has more than once referenced the significance of Blue Planet in relation to impacting public opinion, one of the driving factors leading to the European Commissions 'Single-Use Plastics Directive' [37-39]. This directive outright bans selected single-use plastic products for which an alternative exists, in effect taking away our toys because we cannot play (or design) nicely. However, the Blue Planet is not a statement of irrefutable scientific fact (e.g., we do not know what actually killed the calf) and only represents a single perspective within academic debate for which a number of counter arguments exist (for example the threat reality versus threat perception debate between Burton [40] and Kramm et al. [41]). The statement made by the television show was that plastic waste is 'bad', a result of human action and is easily avoidable, this is all true, however, the message is out of context and not presented or scaled in relation to other more significant issues. Therefore, the resulting hyperreality has become a cloak to the primary threats to ocean stability, such as climate change and overfishing [42]. This could lead to individuals believing that not using a plastic straw is important for saving the planet, but it is not, it is just a simple and easy to achieve act for societal approval (i.e.,' doing my bit to help') that requires negligible mental or financial investment. Not without further corrective action across all areas of human activity can a significant change actually be realised. Shin and Bull in their paper Three Dimensions of Design for Sustainable Behaviour [43] point towards Design for Sustainable Behaviour (DfSB) as an emergent domain within sustainable design theory and practice through which individual, behaviourally driven action could be moderated by applied design intervention. Through the three identified dimensions of DfSB strategies (information, motivation, and empowerment), not only could values and actions that impact upon the environment be dissected and better understood by the designer, but pro-active design attempts could be made to correct or build upon these 'rational' actions towards more substantial and more appropriate cumulative endeavour. Actions which will be slightly less comfortable and gratifying than buying a movie-of-the-day emblazoned 'bag-for-life' (a 
paradoxical artefact in and of itself) will be required and DfSB, as presented by Shin and Bull within this Special Issue, may be one approach through which this change could be negotiated.

However, without check or correction, and perhaps more importantly, an associated ethical bounding, the artificial narrative could also be used to purposely circumvent the truth, creating a malignant collective hyperreality to persuade action towards an individual's benefit. Through the presentation of 'alternative facts', selected omission, fabricated 'fake news', and repeated antiscience rhetoric [44,45], this combination of misinformation and disinformation can create new norms and perceptions; a form of Design for Unsustainable Behaviour. In 2017, little over half of Americans believed that global warming was being caused by human action (56\%) [46]. This can be attributed to an alignment with the identify of a political party, rather than an underlying political ideology. In other words, 'I believe this to be true, because I identify as a member of $x$ party, and $x$ party holds this to be true', as opposed to 'I believe this to be true, because I identify with y social ideas, and y social ideas hold this to be true'. Driven by party rhetoric, and not independent reasoning, it is not surprising that only $40 \%$ of Conservative Republicans in 2017 believed that global warming was happening at all, compared to $97 \%$ of Liberal Democrats [46-48]. This is perhaps even less surprising given that the Senator who gave a speech to the senate stating that global warming is "the greatest hoax ever perpetrated on the American people", the eight year Bush administration that regularly described the "uncertainty" of climate change and the dismissive call for "sound science", and more recently the 45th President of the United States Donald Trump claiming that climate change was "created by and for the Chinese in order to make U.S. manufacturing non-competitive", are all Republican [49,50]. For one form of economic motive or another, anthropogenic climate change denial from those in power has reinforced, mainstreamed, and legitimised the hyperreal narrative that climate change is a fabrication based on, and quoting Trump again, "faulty science and manipulated data" [50].

In Dutta's paper, Design Engagements at the Margins of the Global South: De-Centering the "Expert" Within Me [51], he reflects upon his own design research practice, coming from the Global North, and his engagement with rural communities situated in eastern India, part of the Global South. In this Special Issue paper, Dutta shares his reflections and experiential learnings to support design scholars from the Global North in future engagements within the Global South, promoting self de-constructive reflection and respectful co-creation, moving towards the self-organisation of indigenous participants and communities. One could also argue in the context of hyperreality, and the ubiquitous bombardment of false information, that this approach could also offer value in a Global North to Global North context as a means of reawakening to the natural world around us. Complementing this approach, Hakio and Mattelmäki in their Special Issue paper Future Skills of Design for Sustainability: An Awareness-Based Co-Creation Approach [52], discuss awareness-based competencies and the concept of the invisible inner dimension of sustainability. Once we have intelligently recognised and engaged with both our internal (from the perspective of the self) and external (from the perspective of the whole) interconnectedness within a situated experience, we can become holistically transformed; in turn a powerful catalyst towards larger scale co-created change, and a key future skill for design for sustainability practitioners. By challenging one's own knowledge construction and through an actioned process of situated experience, awareness, and reflection, we are presented with complimenting approaches and methods through which reality could be truly understood and even relearned; false narratives and deleterious intent can be challenged and alternatives explored in collaboration with others.

\section{The Future of Design for Sustainability}

So, where does this leave design when the objective scientific truth is obfuscated, and the hyperreal becomes the new norm which in turn alters social meaning and pressure, leading to significant shifts in political agenda and resulting action? In short, design needs to be separated from being a reactionary knee-jerk to manipulated visions and needs to lead from the front based on what needs to be done. The main aim of this Special Issue is, therefore, to explore more fundamental changes in direction, and to be a call towards being less incremental and passive, especially when interacting with economic and 
political systems (which all design does to some extent). Traditional myopic approaches are now part of the problem, helping to reinforce the agenda of the hyperreal narratives, and are not part of the solution. In the words of Victor Papanek [22], "Design, if it is to be ecologically responsible and socially responsive, must be revolutionary and radical in the truest sense". Within this Special Issue we present eight papers that we believe will realign (and relight) Design for Sustainability towards the right direction.

The Special Issue editors would like to thank the authors of the papers within this Special Issue for their valuable contributions, as well as the reviewers for their time and expertise. Finally, we look forward to the critical debate that this Special Issue brings with it, because, and let us be honest here, Design for Sustainability needs a new agenda.

Author Contributions: The Special Issue The Future of Design for Sustainability and this accompanying editorial Design for Sustainability: The Need for a New Agenda were conceptualized by the first author of this editorial, G.T.W. Both authors of this editorial, G.T.W. and T.B., contributed equally to this Special Issue within their roles as Special Issue Editors, and also contributed significantly as authors to this manuscript. Both authors have read and agreed to the published version of the manuscript. Both authors have read and agreed to the published version of the manuscript.

Funding: This research received no external funding.

Conflicts of Interest: The authors declare no conflict of interest.

\section{References}

1. Gynther, I.; Waller, N.; Leung, K.-P. Confirmation of the Extinction of the Bramble Cay Melomys Melomys Rubicola on Bramble Cay, Torres Strait: Results and Conclusions from a Comprehensive Survey in August-September 2014; Unpublished report to the Department of Environment and Heritage Protection, Queensland Government: Brisbane, Australia, 2016.

2. Price, M. Stronger Protection for Threatened Species. 2019. Available online: https://minister.environment. gov.au/price/news/2019/stronger-protection-threatened-species (accessed on 23 May 2019).

3. Fulton, G.R. The Bramble Cay melomys: The first mammalian extinction due to human-induced climate change. Pac. Conserv. Biol. 2017, 23, 1-3. [CrossRef]

4. Waller, N.L.; Gynther, I.C.; Freeman, A.B.; Lavery, T.H.; Leung, L.K. The Bramble Cay melomys Melomys rubicola (Rodentia: Muridae): A first mammalian extinction caused by human-induced climate change? Wildl. Res. 2017, 44, 9-21. [CrossRef]

5. Watson, J. Bring climate change back from the future. Nature 2016, 534, 437. [CrossRef] [PubMed]

6. Steffen, W.; Grinevald, J.; Crutzen, P.; Mcneill, J. The anthropocene: Conceptual and historical perspectives. Philos Trans. R. Soc. A Math. Phys. Eng. Sci. 2011, 369, 842-867. [CrossRef]

7. Mathias, J.D.; Anderies, J.M.; Janssen, M.A. On our rapidly shrinking capacity to comply with the planetary boundaries on climate change. Sci. Rep. 2017, 7, 1-9. [CrossRef]

8. Azar, C.; Lindgren, K. Methodological and Ideological Options. Socio-ecological indicators for sustainability. Ecol. Econ. 1996, 18, 89-112. [CrossRef]

9. Boehnert, J. Design, Ecology, Politics. Towards Ecocene 2018. [CrossRef]

10. IPCC. Climate Change 2001: The Scientific Basis. Contribution of Working Group I to the Third Assessment Report of the Intergovernmental Panel on Climate Change. Weather 2002, 57, 267-269. [CrossRef]

11. Walther, G.R.; Post, E.; Convey, P.; Menzel, A.; Parmesan, C.; Beebee, T.J.; Fromentin, J.M.; Hoegh-Guldberg, O.; Bairlein, F. Ecological responses to recent climate change. Nature 2002, 416, 389-395. [CrossRef]

12. Steffen, W.; Richardson, K.; Rockström, J.; Cornell, S.E.; Fetzer, I.; Bennett, E.M.; Biggs, R.; Carpenter, S.R.; De Vries, W.; De Wit, C.A.; et al. Planetary boundaries: Guiding human development on a changing planet. Science 2015, 347, 1259855. [CrossRef]

13. Díaz, S.; Settele, J.; Brondízio, E.; Ngo, H.; Guèze, M.; Agard, J.; Arneth, A.; Balvanera, P.; Brauman, K.; Butchart, S.; et al. Summary for Policymakers of the Global Assessment Report on Biodiversity and Ecosystem Services of the Intergovernmental Science-Policy Platform on Biodiversity and Ecosystem Services; IPBES Secretariat: Bonn, Germany, 2019.

14. De Vries, W.; Kros, J.; Kroeze, C.; Seitzinger, S.P. Assessing planetary and regional nitrogen boundaries related to food security and adverse environmental impacts. Curr. Opin. Environ. Sustain. 2013, 5, 392-402. [CrossRef] 
15. Lewis, S.L.; Maslin, M.A. Defining the Anthropocene. Nature 2015, 519, 171-180. [CrossRef] [PubMed]

16. Carrington, D. Why the Guardian is Changing the Language it Uses about the Environment. The Guardian, 17 May 2019.

17. Parliament of the United Kingdom. “The Most Important Issue of Our Time," Opposition Calls to Declare Climate Emergency. Available online: https://www.parliament.uk/business/news/2019/may/mps-debate-theenvironment-and-climate-change/ (accessed on 23 May 2019).

18. Brundtland, G.H. A/42/427 Report of the World Commission on Environment and Development. Our Common Future; WCED: Geneva, Switzerland, 1987.

19. Bhamra, T.A.; Lofthouse, V.A. Design for Sustainability A Practical Approach; Gower Publishing Limited: Aldershot, UK, 2007.

20. Ceschin, F.; Gaziulusoy, I. Evolution of design for sustainability: From product design to design for system innovations and transitions. Des. Stud. 2016, 47, 118-163. [CrossRef]

21. United Nations. Transforming Our World: The 2030 Agenda for Sustainable Development; A/RES/70/1; UN: Geneva, Switzerland, 2015.

22. Papanek, V. Design for the Real World: Human Ecology and Social Change; Bantam Books, Inc.: New York, NY, USA, 1972.

23. Stevenson, N.; Lilley, D.; Lofthouse, V.A.; Cheyne, A. The Complexity of Responsible Design: Key Factors Affecting Industrial Design Consultants Addressing the Greater Needs of Society. In Proceedings of the Sustainable Innovation 11: 'State of the Art' in Sustainable Innovation and Design, 16th International Conference, Farnham, UK, 24-25 October 2011.

24. Hernandez, R.J. Sustainable product-service systems and circular economies. Sustainability 2019, 11, 5383. [CrossRef]

25. United Nations. Paris Agreement under the United Nations Framework Conventions on Climate Change. In Proceedings of the 21st Conference of the Parties, Paris, France, 30 November-12 December 2015; pp. 1-25.

26. Climate Analytics; NewClimate Institute. Climate Action Tracker Warming Projections Global Update December 2018; Climate Analytics: Cologne, Germany, 2018.

27. IPCC. Global Warming of $1.5^{\circ} \mathrm{C}$. In An IPCC Special Report on the Impacts of Global Warming of $1.5^{\circ} \mathrm{C}$ above Pre-Industrial Levels and Related Global Greenhouse Gas Emission Pathways, in the Context of Strengthening the Global Response to the Threat of Climate Change; IPCC: Geneva, Switzerland, 2018.

28. Li, W.T.; Ho, M.C.; Yang, C. A design thinking-based study of the prospect of the sustainable development of traditional handicrafts. Sustainability 2019, 11, 4823. [CrossRef]

29. Corsini, L.; Moultrie, J. Design for social sustainability: Using digital fabrication in the humanitarian and development sector. Sustainability 2019, 11, 3562. [CrossRef]

30. Gaziulusoy, Ï.; Öztekin, E.E. Design for sustainability transitions: Origins, attitudes and future directions. Sustainability 2019, 11, 3601. [CrossRef]

31. Leather, M.; Gibson, K. The consumption and hyperreality of nature: Greater affordances for outdoor learning. Curric. Perspect. 2019, 39, 79-83. [CrossRef]

32. Met Office. Chance of Summer Heatwaves Now Thirty Times More Likely. Available online: https://www.metoffice.gov.uk/about-us/press-office/news/weather-and-climate/2018/2018-uksummer-heatwave (accessed on 23 May 2019).

33. Ogilvie, J.E.; Griffin, S.R.; Gezon, Z.J.; Inouye, B.D.; Underwood, N.; Inouye, D.W.; Irwin, R.E. Interannual bumble bee abundance is driven by indirect climate effects on floral resource phenology. Ecol. Lett. 2017, 20, 1507-1515. [CrossRef]

34. Gatto, G.; McCardle, J.R. Multispecies design and ethnographic practice: Following other-than-humans as a mode of exploring environmental issues. Sustainability 2019, 11, 5032. [CrossRef]

35. Baudrillard, J. Simulacra and Simulation, 26th ed.; The University of Michigan Press: Ann Arbor, MI, USA, 2017.

36. Honeyborne, J.; Brownlow, M. Blue Planet II. 2017.

37. European Commission. Communication from the Commission to the European Parliament, the Council, the European Economic and Social Committee and the Committee of the Regions: A European Strategy for Plastics in a Circular Economy; European Commission: Brussels, Belgium, 2018.

38. Boffey, D. EU Declares War on Plastic Waste. The Guardian, 16 January 2018. 
39. European Commission. Closing Statements by First Vice-President Frans Timmermans on the Reduction of the Impact of Certain Plastic Products on the Environment at the European Parliament's Plenary Session; European Commission: Brussels, Belgium, 2019.

40. Burton, G.A. Stressor Exposures Determine Risk: So, Why Do Fellow Scientists Continue to Focus on Superficial Microplastics Risk? Environ. Sci. Technol. 2017, 51, 13515-13516. [CrossRef] [PubMed]

41. Kramm, J.; Völker, C.; Wagner, M. Superficial or Substantial: Why Care about Microplastics in the Anthropocene? Environ. Sci. Technol. 2018, 52, 3336-3337. [CrossRef] [PubMed]

42. Stafford, R.; Jones, P.J.S. Viewpoint-Ocean plastic pollution: A convenient but distracting truth? Mar. Policy 2019, 103, 187-191. [CrossRef]

43. Shin, H.D.; Bull, R. Three dimensions of design for sustainable behaviour. Sustainability 2019, 11, 4610. [CrossRef]

44. Apitz, S.E.; Backhaus, T.; Chapman, P.M.; Landis, W.; Suter, G. Science, antiscience, and environmental decision making: A call to action. Integr. Environ. Assess. Manag. 2017, 13, 557-559. [CrossRef]

45. Cooke, N.A. Posttruth, Truthiness, and Alternative Facts: Information Behavior and Critical Information Consumption for a New Age. Libr. Q. 2017, 87, 211-221. [CrossRef]

46. Ballew, M.T.; Leiserowitz, A.; Roser-Renouf, C.; Rosenthal, S.A.; Kotcher, J.E.; Marlon, J.R.; Lyon, E.; Goldberg, M.H.; Maibach, E.W. Climate Change in the American Mind: Data, Tools, and Trends. Environ. Sci. Policy Sustain. Dev. 2019, 61, 4-18. [CrossRef]

47. Hornsey, M.J.; Harris, E.A.; Bain, P.G.; Fielding, K.S. Meta-analyses of the determinants and outcomes of belief in climate change. Nat. Clim. Chang. 2016, 6, 622-626. [CrossRef]

48. Mildenberger, M.; Leiserowitz, A. Public opinion on climate change: Is there an economy-environment tradeoff? Environ. Polit. 2017, 26, 801-824. [CrossRef]

49. Dunlap, R.E.; McCright, A.M. Organized Climate Change Denial. In The Oxford Handbook OF Climate Change and Society; Oxford University Press: Oxford, UK, 2011; Volume 1, pp. 144-160. [CrossRef]

50. De Pryck, K.; Gemenne, F. The Denier-in-Chief: Climate Change, Science and the Election of Donald J. Trump. Law Crit. 2017, 28, 119-126. [CrossRef]

51. Dutta, U. Design engagements at the margins of the global South: De-centering the "expert" within me. Sustainability 2019, 11, 5675. [CrossRef]

52. Hakio, K.; Mattelmäki, T. Future skills of design for sustainability: An awareness-based co-creation approach. Sustainability 2019, 11, 5247. [CrossRef] 